\title{
Melanoma cutâneo: estudo prospectivo de 65 casos $^{*}$ Cutaneous melanoma: prospective study of 65 cases $^{*}$
}

\author{
Nurimar C. Fernandes ${ }^{1}$ \\ Tullia Cuzzi ${ }^{4}$
}

\author{
Roberto Calmon ${ }^{2}$ \\ Cesar S. Claudio da Silva
}

Juan P. Maceira ${ }^{3}$

\begin{abstract}
BACKGROUND: Incidence and mortality of cutaneous melanoma are increasing all over the world. The data base for the Brazilian population is still inadequate.

OвJестіves: Prospective study of 65 cases seen at University Hospital Clementino Fraga Filho, from 1993 to 2003 .

Methods: Patient's age, sex, ethnic group, anatomic site, clinical histological presentation and staging were analyzed.

RESULTS: The case distribution was $64.7 \%$ aged 40 to 69 years, males (49.2\%) and females (50.8\%), majority white (83.1\%), most lesions in the trunk $(35.3 \%)$, more frequently of the clinical histological superficial spreading type (63\%/30.7\%) and significant relationship between foot acral type in non-whites. According to American Joint Committee on Cancer 2002 system, 22 cases (33.8\%) in stage IA, 14 (21.5\%) melanomas in situ, and one indeterminate case.

Conclusions: Primary cutaneous melanoma in the present study has a similar pattern to other published series and higher frequency of stage IA and in situ melanomas.

Keywords: Prospective studies; Melanoma/diagnosis; Melanoma/epidemiology; Skin neoplasms/pathology.

Resumo: FunDAMENTOS: A incidência e a mortalidade por melanoma cutâneo vêm aumentando em todo o mundo. Os registros brasileiros de bases populacionais não refletem precisamente a real dimensão do problema.

OвJETIVOS: Estudo prospectivo de 65 casos de melanoma cutâneo observados no Hospital Universitário Clementino Fraga Filbo no período de 1993 a 2003.

MÉTODOS: Foram analisadas as variáveis idade, sexo, cor, localização, tipos clínico-histológicos e estadiamento.

RESULTADOS: 64,7\% na faixa etária de 40 a 69 anos, distribuição etária homogênea entre o sexo masculino (49,2\%) e o sexo feminino (50,8\%), predominância de brancos (83\%), localização no tronco (35,3\%), tipo clínico-bistológico expansivo superficial (63\%/30,7\%) e relação de significância entre tipo acral localizado no pé em não brancos. Segundo o American Joint Committee on Cancer, em 2002, 22 casos (33,8\%) no estádio IA, 14 (21,5\%) melanomas in situ e um caso indeterminado. CONCLUSÕES: O melanoma cutâneo primário na amostra estudada mostrou padrões semelhantes aos classicamente reconhecidos e maior freqüência do estádio IA e melanoma in situ.

Palavras-chave: Estudos prospectivos; Melanoma/diagnóstico; Melanoma/epidemiologia; Neoplasias cutâneas/patologia.
\end{abstract}

Received on September 08, 2003.

Approved by the Consultive Council and accepted for publication on December 17, 2004

* Work done at the Services of Dermatology, Oncology, Pathological Anatomy and Plastic Surgery of the University Hospital Clementino Fraga Filho, Federal University of Rio de

Janeiro (HUCFF-UFRJ)

${ }^{1}$ Adjunct Professor of Dermatology, Department of Clinical Medicine, FM-UFRJ

2 M.D., Oncology Service, HUCFF-UFRJ

${ }^{3}$ Adjunct Professor of Pathology, Department of Pathology, FM-UFRJ

${ }^{4}$ Adjunct Professor of Pathology, Department of Pathology, FM-UFR]

${ }^{5}$ Adjunct Professor of Plastic Surgery, Department of Surgery, FM-UFRJ

(C2005 by Anais Brasileiros de Dermatologia

An Bras Dermatol. 2005; 80(1):25-34. 


\section{INTRODUCTION}

Some basic rules enable the immediate recognition of cutaneous melanoma in melanocytic lesions: color, size, form and surface changes; fast growth, desquamation, ulceration, bleeding, pruritus, pain and development of papular or nodular areas on pigmented maculae. ${ }^{1}$

Traditionally cutaneous melanoma is subdivided into four types: $:^{2,3}$

Superficial spreading melanoma (SSM) - éthe most frequent with $70 \%$ of cases; fourth and fifth decades; in the trunk and lower limbs. Several colors, such as chestnut, black, rosy, violet; central hypopigmentation and peripheral expansion; the translucent dark-ash shade is highly suggestive. Chronic course, and, after a period of several months to years, elevated nodules, bleeding or transudation can appear, which characterize the most advanced stage of vertical growth.

Nodular melanoma (NM) - is the second most common, accounting for 15 to $30 \%$ of the cases, in the fifth and sixth decades of life, male predominance with a proportion of $2: 1$. It presents as an elevated papular lesion, with a brown, black or bluish color. Ulceration and bleeding are frequent; there is an amelanotic variant, with an erythematous surface. The expression is reserved to primitively nodular lesions, or that is, without a prior phase of radial growth.

Acral lentiginous melanoma (ALM) - in the palmoplantar areas, digital extremities, mucous and semimucous membranes; it is more frequent in non-whites (35 to $60 \%$ ). There is no gender predominance; seventh decade of life. In the digital extremities it can present as a brownish subungual tumoral lesion, striated melanonychia, longitudinal fragmentation of the ungual blade, besides chronic and persistent paronychia.

PTo aid in the early detection of subungual melanomas, the "ABCDEF system" has been proposed: ${ }^{4}$

A (age): 20-90 years with peak incidence between the fifth and seventh decades, non whites.

B (nail band): chestnut-black pigmentation with width $\geq 3 \mathrm{~mm}$ and irregular border.

$C$ (change): rapid increase in the size of the band.

$\mathrm{D}$ (digit involved): thumb $>$ hallux $>$ index finger, only, dominant hand.

E (extension): involvement of the lateral and proximal ungual fold or free border of the nail.

F (family or personal history): prior melanoma or dysplastic nevus syndrome.

Malignant lentigo melanoma (MLM) - oinfrequent, $5 \%$ of the cases; sixth and seventh decades of life; it appears in areas of solar lentigo that presents as a brownish or black macula, with sharp and irregular borders, reaching several centimeters in diameter, located in the face $(90 \%)$, hands and lower limbs (10\%). After a long period of radial growth, there is a perpendicular invasion to the surface, characterized clinically by the presence of an elevated nodule, amid diverse pigmentation tones, such as dark-chestnut, black and bluish. In this phase, ulcerations, bleeding and formation of crusts can occur.

Melanoma can present clinically as metastatic disease, without evidence of primary cutaneous involvement; the incidence of melanoma with unknown primary site is from 1 to $15 \%$. Some theories have been elaborated to try to explain this phenomenon: ${ }^{5}$ primary lesions removed surgically without a histopathologic study of the material; melanoma of a primary cutaneous site, with clinical appearance of a benign lesion; primary lesion located in scalp, gastrointestinal tract, suprarenal, meninges, retina, palate, vulva, vagina, anorectal area; and primary lesion with spontaneous regression (hypochromic macula), due to immunological phenomena.

The published Brazilian cases exhibit a prevalence among females, white ethnic group, age group over 40 years, location in the trunk and limbs and clinical-histological type NM and SSM (Table 1).

This work presents a prospective study of cutaneous melanoma based on a multidisciplinary protocol.

\section{PATIENTS AND METHODS}

In the period comprising 1993 to 2003, 65 cases of cutaneous melanoma in the University Hospital Clementino Fraga Filho were submitted to the following routine:

\section{1) Biopsy}

a) excisional biopsy was the choice technique for confirmation of clinical suspicion, with margins of $1 \mathrm{~cm}$ (face) ${ }^{18}$ or $2 \mathrm{~cm} ;{ }^{19}$ suture of the border for simple closure by skin grafts when the primary closure was not achieved. In lesions of the lower and upper limbs, the direction of the operative wound was longitudinal; in the face and trunk, it followed the tension lines of the skin. Breslow thickness in the histopathological exam of the sample defined the optimal margins: $\leq 1 \mathrm{~mm}(1 \mathrm{~cm}$ margin) and $>1 \mathrm{~mm}$ ( $2 \mathrm{~cm}$ margin), establishing the need for re-excision to amplify the margins. ${ }^{1821}$

b) incisional punch biopsy indications; lesions located in the face, hands, feet and subungual regions, with diameter $>1.5 \mathrm{~cm}$ or in those in which an excisional biopsy would demand an extensive procedure. A $6 \mathrm{~mm}$ punch was used to include all the skin layers and subcutaneous cellular tissue in the most elevated area of the lesion. ${ }^{20,22}$ Breslow in the incisional biopsy was considered provisory.

\section{2) Histopathological staging \\ - histological types: \\ - melanoma in situ \\ This histological definition was used in cases}


TABle 1: Cutaneous melanoma: Brazilian cases (1983-2003)

\begin{tabular}{|c|c|c|c|c|c|c|c|}
\hline Author, Year & $\begin{array}{l}\mathrm{N}^{\circ} \text { of } \\
\text { Cases }\end{array}$ & Color(\%) & Gender(\%) & $\begin{array}{l}\text { Age } \\
\text { (Years)(\%) }\end{array}$ & Localization(\%) & $\begin{array}{l}\text { Clinical-Histolo- } \\
\text { gical Type (\%) }\end{array}$ & $\begin{array}{l}\text { Breslow/ } \\
\text { Thickness (\%) }\end{array}$ \\
\hline Pinheiro, $2003^{6}$ & 32 & W (87.5) & F (78) & $61-80(43.75)$ & UM/LM (50) & NM (45) & $<0.75 \mathrm{~mm}(42.3)$ \\
\hline Maia, $2002^{7}$ & 190 & W (91.9) & F (58.9) & $55.9(-)$ & - & SM (41.1) & - \\
\hline Lapa, $2002^{8}$ & 115 & $W(94)$ & F (64) & $40-59(43.5)$ & Axial (61) & NM (19.1) & $>1.5 \mathrm{~mm}(31.5)$ \\
\hline Bakos, $2002^{9}$ & 103 & W (100) & F (66.9) & $52,8 \quad(-)$ & $\mathrm{T}(25.2)$ & SSM (61.16) & - \\
\hline Gon, $2001^{10}$ & 303 & - & F (54.6) & $56(42.24)$ & $\mathrm{T}(32.01)$ & NM (41.09) & $>0.75 \mathrm{~mm}(75)$ \\
\hline Criado, $1999^{11}$ & 222 & W (98.19) & F (69.36) & $60-69(23.42)$ & LM (32.88) & - & $\leq 1.5 \mathrm{~mm}(45.44)$ \\
\hline Ponzio, $1998^{12}$ & 167 & W (100) & $\mathrm{F}(50.8)$ & $60-69(-)$ & UM/LM (41.3) & SSM (35.3) & - \\
\hline Donato, $1997^{13}$ & 58 & - & $\mathrm{F}(74.1)$ & $>60(-)$ & LM (29.6) & - & $\leq 75 \mathrm{~mm}(48.2)$ \\
\hline Fernandes, $1996^{3}$ & 47 & W (84.4) & F (57.4) & $40-59(44.6)$ & $\mathrm{T}(29.9)$ & MLM (29.8) & - \\
\hline Castro, $1996^{14}$ & 20 & W (100) & M (65) & $45.1(18,8)$ & $\mathrm{T}(50)$ & - & $\leq 1 \mathrm{~mm}(50)$ \\
\hline Bakos, $1991^{15}$ & 153 & W (100) & $\mathrm{F}(60.13)$ & $60-70(23)$ & - & SSM (51.6) & - \\
\hline Dick, $1989^{16}$ & 161 & - & - & $40-49(24.2)$ & - & - & - \\
\hline Minelli, $1983^{17}$ & 59 & W (96.61) & M (57.62) & $46-50(16.9)$ & $\begin{array}{l}\mathrm{LM}(25, .4) \\
\mathrm{T}(25.4)\end{array}$ & - & - \\
\hline
\end{tabular}

Key:

- : not given

UM: upper limb

LM: lower limb

F: female

M: male
W: white

T: trunk

SSM: superficial spreading melanoma

MLM: malignant lentigo melanoma

NM: nodular melanoma of: atypical melanocytes confined to epidermis; architecture of the epidermal structure is altered; hyperplasia of the basal melanocytes, without concentration in the interpapillary crests; melanocytes distributed throughout the epidermis; continuous cytological atypia (Clark's level I). According to various authors, it is not necessary to measure the thickness, because, these cases do not represent an invasion.

- superficial spreading melanoma (SSM) atypical melanocytes in several layers of the epidermis; dense lymphocytic infiltrate in the subjacent dermis; in the vertical growth phase, thecae in the papillary dermis and the epidermal "shoulders" extending beyond the dermal compartment of the tumor.

- nodular melanoma (NM)

starting from the dermoepidermal junction, a great extension of neoplastic cells to the dermis; inexpressive involvement of the epidermis; epidermal component not exceeding in laterality the tumor limits; the term nodular is reserved for lesions without a previous phase of radial growth.

- acral lentiginous melanoma (ALM)

atypical melanocytic proliferation, dendritic aspect, linear, predominant along the basal layer and its border; tendency for epidermal hyperplasia and absence of elastosis; very dense and lichenoid inflammatory infiltrate.

malignant lentigo melanoma (MLM) contiguous proliferation of atypical melanocytes, of dendritic aspect, along the basal layer with disappearance of the basal keratinocytes; thinning of the epidermis and signs of chronic actinic damage with solar elastosis.

- Breslow thickness

Breslow thickness determines the tumoral thickness - vertical dimension starting from the deepest point of invasion to the top of the granular layer or the most superficial cell in case of ulceration - using a micrometric eyepiece subdivided into $\leq 1 \mathrm{~mm} ; 1.01 \mathrm{~mm}$ to $2 \mathrm{~mm} ; 2.01$ to $4 \mathrm{~mm}$; and $>4 \mathrm{~mm}$. In the new staging system (American Joint Committee on Cancer), the thickness is defined in limits of $1 \mathrm{~mm}, 2 \mathrm{~mm}$ and $4 \mathrm{~mm} .{ }^{23}$

- Clark's level

The level of invasion in the classification proposed by Clark $^{24}$ comprises: level I (intraepidermal growth), level II (invasion of the papillary dermis), level III (reaching the limit between the papillary and reticular dermis), level IV (invasion of the reticular 
dermis) and level V (invasion of the subcutaneous cellular tissue). It is a predictive factor independent of fine melanoma, but not for thicker lesions. In this manner, the invasion level is incorporated only in the definitions of melanomas $\leq 1 \mathrm{~mm}^{23}$ (Chart 1).

\section{3) Clinical staging}

a) investigation for evidence of metastatic disease: fever, migraine, asthenia, weight loss, bone pain, neurological and respiratory signs and symptoms. ${ }^{20,21}$

b) physical exam of the ski

- metastasis in-transit: lesions in the area of lymphatic drainage, $5 \mathrm{~cm}$ from the origin of the primary tumor.

- ssatellitosis - lesions around the tumor within a radius of $5 \mathrm{~cm}$.

c) physical exam of the regional lymph nodes

- impalpable (clinically occult).

Evaluation by tomography and/or ultrasonography of the lymph nodal chains was performed whenever there were doubts regarding the palpation. ${ }^{25}$ The microstaging (histopathological) by selective ganglionar dissection (study of the sentinel lymph node) was done in two cases.

- palpable: macrometastasis, clinically detectable, was confirmed by therapeutic ganglionar dissection; the involvement was classified according to the number of metastatic lymph nodes, with cutoffs of 1,2 to 3 and $\geq 4$ (Chart 1$){ }^{23}$

d) general physical exam: liver, spleen and especially the central nervous system ${ }^{20,21}$

\section{4) Laboratory exams}

- in the absence of signs and symptoms of metastasis: blood count; ESR; dosage of glucose, urea, creatinine and lactate dehydrogenase (LDH); tests of hepatic function; and X-ray of the pleuropulmonary fields. ${ }^{20,21}$

- in clinically metastatic cases the following were also performed: skull CT, chest CT, abdominal and pelvic CT, bone scintography, and X-ray of skeleton if the scintography revealed alterations..$^{20,21}$

\section{5) Follow-up}

The routine for follow-up of the cases was based on Breslow thickness (Chart 2); AJCC (2002) does not define such management (Chart1). This ambulatory follow-up, for an unspecified period is accomplished by the first author, except for cases of $i n$ situ melanomas that have received hospital discharge.

\section{6) Statistical analysis}

For comparison of proportions the Chi-square test was used $\left(\chi^{2}\right)$ or Fisher's exact test when Chi- square test could not be used; the 5\% level of significance was adopted.

\section{RESULTS}

The group studied comprised 26 white men (40\%) and six non-white men (black and mulattos) (9.2\%), 28 white women (43.1\%) and five non-white women (black and mulattos) $(7.6 \%)$ in the age group from 20 to 89 years. The age distribution among the sexes was homogeneous $(\mathrm{p}=0.47)$, and there was prevalence of whites (83\%). The disease prevailed in the age groups from 40 to 69 years $(64.7 \%)$ (Table 2 ).

Superficial spreading melanoma occurred in 41 cases (63\%). Considering only the superficial spreading and the acral lentiginous clinical types, for purposes of comparison, a significant relationship was observed $(p=0.0007)$ between the non-whites and the acral lentiginous type; on the other hand it was observed that there was no significant relationship ( $\mathrm{p}$ $=0.45$ ) between clinical type and gender (Table 3 ).

Location in the trunk occurred in 23 cases (35.3\%). A significant relationship was observed ( $p=$ $0.0006)$ between location in the foot and non-white color. No significant relationship was observed $(\mathrm{p}=$ 0.67 ) between tumor location and gender (Table 4).

Histologically, 20 superficial spreading melanomas were verified (30.7\%), 14 melanomas in situ (21.5\%) and 10 nodular melanomas (15.3\%) (Table 5).

According to the staging, $21.5 \%$ of melanomas were in situ (14/65), 33.8\% of the cases $(22 / 65)$ were in stage IA, eight cases (IB), four cases (IIA), five cases (IIB), no cases (IIC), four cases (IIIA), two cases (IIIB), one case (IIIC), four cases (IV); in one case Breslow thickness was not determined; $29.1 \%$ of the cases $(19 / 65)$ reached five-year survival at the time of the data analysis. (Table 6).

\section{DISCUSSION}

Incisional biopsy in suspected melanoma lesions is a simple ambulatory procedure and it provides representative tissue. On the other hand, no increase in the percentages of local recurrence or any changes in the survival curves was registered with the method. ${ }^{22}$ These data from recent literature indicate that the procedure is safe.

In six cases, incisional biopsy showed Breslow thickness from 0.18 to $2.16 \mathrm{~mm}$, and, after resection, the histopathological finding for the sample was melanoma in situ. This finding is explained by the fact that a $6 \mathrm{~mm}$ punch was used, and the highest and thickest areas were always chosen. In one case, the histopathological finding from the incisional biopsy was melanoma in situ, however, after complete removal, the thickness was $0.36 \mathrm{~mm}$; such that in all of 
CHART 1: Stage of cutaneous melanoma, AJCC - 2002

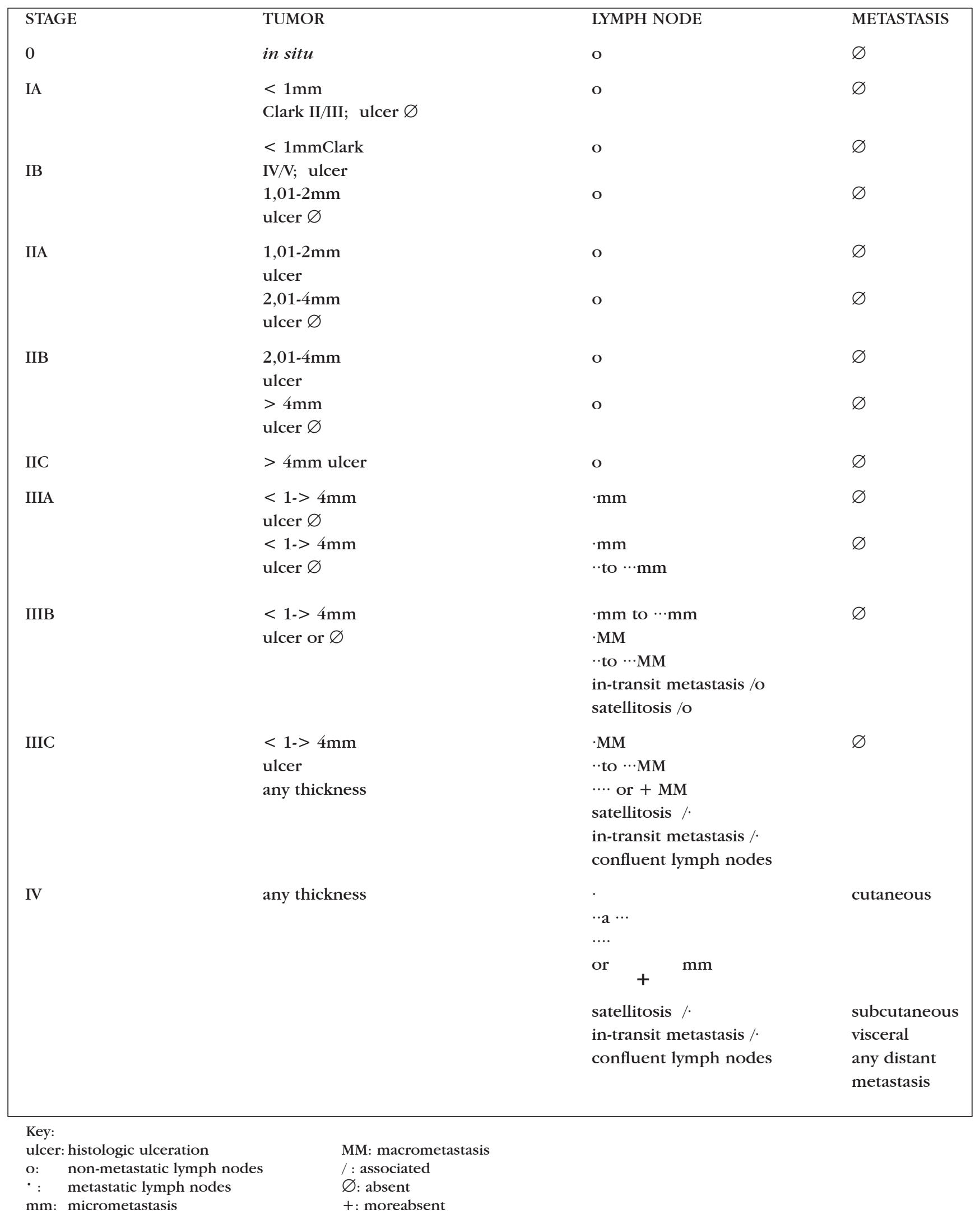


Chart 2: Multidisciplinary protocol for cutaneous melanomas (HUCFF - UFRJ)

\begin{tabular}{|c|c|c|}
\hline Groups & Criteria & Management / F ollow-up \\
\hline I & $\begin{array}{l}\cdot \leq 1 \mathrm{~mm} \\
\cdot \text { without clinical evidence of metastasis } \\
\text { (distant lymph node) }\end{array}$ & $\begin{array}{l}\text { - resection of lesion: } 1 \mathrm{~cm} \text { margin } \\
\cdot \text { dermatological exam and of the lymph nodes: every } \\
\text { six months (first two years) then annually }\end{array}$ \\
\hline II & $\begin{array}{l}\cdot>1 \text { a } 4 \mathrm{~mm} \\
\cdot \text { without clinical evidence of metastasis } \\
\text { (distant lymph node) }\end{array}$ & $\begin{array}{l}\text { - resection of lesion: } 2 \mathrm{~cm} \text { margin } \\
\text { - dermatological exam and of the lymph nodes: every two } \\
\text { months (two years) then every six months } \\
\text { - chest X-ray and hepatogram: every six months } \\
\text { (two years) then annually }\end{array}$ \\
\hline III & $\begin{array}{l}\cdot>4 \mathrm{~mm} \\
\cdot \text { without clinical evidence of metastasis } \\
\text { (distant lymph node) }\end{array}$ & $\begin{array}{l}\text { - resection of lesion: } 2 \mathrm{~cm} \text { margin } \\
\text { - dermatological exam and of the lymph nodes: every two } \\
\text { months (two years) then every six months } \\
\text { - chest X-ray and hepatogram: every six months } \\
\text { (two years) then annually }\end{array}$ \\
\hline IV & $\begin{array}{l}\cdot \text { any thickness } \\
\cdot \text { satellitosis } \\
\cdot \text { in-transit metastasis }\end{array}$ & $\begin{array}{l}\text { - Clinical exam every four months } \\
\text { - chest X-ray and hepatogram: every six months } \\
\text { - imaging exams focused on the region of recurrence: } \\
\text { every four months } \\
\text { - resection of locoregional and limited visceral metastases } \\
\text { - individualized chemotherapy }\end{array}$ \\
\hline V & $\begin{array}{l}\cdot \text { any thickness } \\
\cdot \text { extensive cutaneous disease } \\
\cdot \text { non-resectable metastasis to regional } \\
\text { lymph node }\end{array}$ & $\begin{array}{l}\text { - chemotherapy } \\
\text { radiotherapy in the cerebral and bone (spinal) metastases } \\
\text { radiotherapy to be considered in the localized nodal } \\
\text { recurrences }\end{array}$ \\
\hline & - extensive visceral metastasis & localizadas \\
\hline
\end{tabular}

the cases the largest Breslow thickness prevailed.

The margins of the excisional biopsy referred to are from 1 to $2 \mathrm{~mm}^{2}$ and 1 to $2 \mathrm{~cm}^{19}$, and, for melanoma in situ, $0.5 \mathrm{~cm}$ to $1 \mathrm{~cm} .{ }^{22}$ The authors opted for the largest, since they would already match the Breslow thickness $(<1 \mathrm{~mm} / 1 \mathrm{~cm} ;>1 \mathrm{~mm} / 2 \mathrm{~cm})$.

For cases in which there were doubts regarding palpation of the lymph nodes (i.e. palpable/impalpa- ble) tomography was used, which did not reveal enlarged lymph nodes. The differential diagnosis between reactional and metastatic lymph nodes is considered possible by ultrasonography, even when impalpable. The following characteristics of metastatic involvement have been described: lymph nodes with a globular aspect with bosselated surface, absence of hilum and hypoechogenic in hypoe-

TABLE 2: Distribution of the cases according to age group, gender and color

\begin{tabular}{|c|c|c|c|c|c|}
\hline \multirow[b]{2}{*}{ Age Group } & \multicolumn{2}{|c|}{ White } & \multicolumn{2}{|c|}{ Non-White } & \multirow[b]{2}{*}{ Total / \% } \\
\hline & Male & Female & Male & Female & \\
\hline $20-29$ & 1 & - & - & - & 11.5 \\
\hline $30-39$ & 4 & 5 & 1 & - & 1015.4 \\
\hline $40-49$ & 4 & 10 & 1 & - & $15 \quad 23.1$ \\
\hline $50-59$ & 3 & 3 & 2 & 2 & $10 \quad 15.4$ \\
\hline $60-69$ & 10 & 6 & 1 & - & 1726.2 \\
\hline $70-79$ & 2 & 3 & 1 & 3 & $9 \quad 13.8$ \\
\hline $80-89$ & 2 & 1 & - & - & 4.6 \\
\hline Total/\% & $2640 \%$ & 2843.1 & 69.2 & 57.6 & 65100 \\
\hline
\end{tabular}

Source: HUCFF - UFRJ (1993-2003)

$\mathrm{p}=0,47$ 
TABLE 3: Distribution of cases according to color, gender and clinical form

\begin{tabular}{|c|c|c|c|c|c|}
\hline \multirow[b]{2}{*}{ Clinical Form } & \multicolumn{2}{|c|}{ Whites } & \multicolumn{2}{|c|}{ Non-Whites } & \multirow[b]{2}{*}{ Total / \% } \\
\hline & Male & Female & Male & Female & \\
\hline Superficial Spreading & 19 & 20 & 2 & - & $41-63$ \\
\hline Acral Lentiginous & 4 & 4 & 2 & 5 & $15-23$ \\
\hline Nodular & 3 & 4 & 1 & - & $8-12.3$ \\
\hline Malignant Lentigo & - & - & 1 & - & $1-1.5$ \\
\hline Total / \% & $26-40$ & $28-43.1$ & $6-9.2$ & $5-7.6$ & $65-100$ \\
\hline
\end{tabular}

chogenicity. ${ }^{25}$

In one case of acral melanoma, during the first postoperative month (transmetatarsal amputation) the patient developed elastic lymph node enlargement, with little pain, in the inguinal satellite chain. Therapeutics with cephalexin $(50 \mathrm{mg} / \mathrm{kg} / \mathrm{day} / \mathrm{VO})$ was attempted for 14 days, considering the possibility of infection in the stump. There was involution of the lymph nodes. The use of antibiotic therapy as a resource in the definition of metastatic versus inflammatory adenomegaly is a practice in Oncology, although not cited for melanomas.

The indications for sentinel lymph node technique (SL) have been broadened, since, at first they were limited to a thickness $>0.75 \mathrm{~mm}$, non-ulcerated tumors of the extremities ( $1 \mathrm{~mm}$ to $2 \mathrm{~mm}$ ) in patients under 60 years of age..$^{22}$ In tumors of the head and neck, there have been reports of less success due to the greater complexity, possibility of permanent tattoo by the stain and difficulty in locating SL; the limitations are determined in the trunk by the ambiguity of the lymphatic drainage. The Melanoma Committee of AJCC (2002) recommends that all patients with clinically negative regional lymph nodes are submitted to SL test, with the Breslow thickness defined as $1 \mathrm{~mm}$ and $4 \mathrm{~mm} .{ }^{23}$ The definition of clinically negative lymph nodes is inherently difficult; the inflammatory adenopathy presents with increased volume of the lymph nodes, painful or painless, coalescent or not, symmetrical. Neoplastic adenopathy has marked asymmetry, which can also exist in the inflammatory adenopathies, however, as a rule, these present a smaller volume. The coalescence is singular to chronic inflammations and also metastization due to proximity with the neoplastic process with invasion of the ganglionar capsule. Fistulization occurs in acute infections; the consistency of the ganglionar mass has a propedeutic value, because in inflammatory and infectious processes the lymph nodes become hard when the distention of the capsule reaches its maximum, having first passed through the stages of being soft and elastic. The hard consistency, which can at times be petrified, even from the beginning, is a characteristic of neoplastic processes.

For the GBM (Brazilian Melanoma Group), the indications for SL study are as follows: ${ }^{26}$ Breslow $\geq$ $0.76 \mathrm{~mm}$; and Breslow $<0.76 \mathrm{~mm}$ only in cases in which it is associated to ulceration and/or to histological regression, Clark IV / V.

Evaluation of the sentinel lymph node was done in two cases.

Case 47: woman, 76 years old, white, non-ulcerated acral melanoma, resection was performed with $1 \mathrm{~cm}$ margin, Breslow $>4 \mathrm{~mm}$, inguinal regional lymph nodes palpable. As ultrasonography and abdominopelvic CT did not characterize metastasis, it was decided to evaluate the sentinel lymph node. SL submitted to exeresis, negative imprint; absence of

TABLE 4: Distribution of cases according to color, gender and localization

\begin{tabular}{lcccccc}
\hline \multirow{2}{*}{ Localization } & \multicolumn{2}{c}{ Whites } & & \multicolumn{2}{c}{ Non Whites } & \multirow{2}{*}{ Total /\% } \\
\cline { 2 - 4 } & Male & Female & & Male & Female & \\
Trunk & 8 & 13 & 2 & - & $23(35.3)$ \\
Members & 8 & 7 & 1 & - & $16(24.6)$ \\
Foot & 4 & 4 & 2 & 5 & $15(23)$ \\
Head & 6 & 4 & 1 & - & $11(16.9)$ \\
\hline Total / \% & $26(40)$ & $28(43.1)$ & $6(9.2)$ & $5(7.6)$ & $65(100)$ \\
\hline
\end{tabular}

Source: HUCFF - UFRJ (1993-2003)

$\mathrm{p}=0,0006$

$\mathrm{p}=0,67$ 
TABLE 5: Distribution of cases according to clinical and histological type

\begin{tabular}{|c|c|c|c|c|c|c|c|c|c|c|c|}
\hline \multirow{2}{*}{$\begin{array}{l}\text { Clinical } \\
\text { type }\end{array}$} & \multirow{2}{*}{$\begin{array}{l}\mathrm{N}^{\mathrm{O}} \text { of } \\
\text { cases }\end{array}$} & \multicolumn{9}{|c|}{ Histological type / No of cases } & \multirow[b]{2}{*}{$\begin{array}{l}\text { Not } \\
\text { classified }\end{array}$} \\
\hline & & $\overline{S S M}$ & in situ & NM & UNM & ALM & MLM & amelanotic & NM & desmoplastic & \\
\hline $\begin{array}{l}\text { Superficial } \\
\text { spreading }\end{array}$ & 41 & 19 & 14 & - & - & - & - & - & 1 & 1 & 6 \\
\hline $\begin{array}{l}\text { Acral } \\
\text { lentiginous }\end{array}$ & 15 & 1 & - & 3 & 4 & 2 & - & 1 & - & - & 4 \\
\hline Nodular & 8 & - & - & 7 & 1 & - & - & - & - & - & - \\
\hline $\begin{array}{l}\text { Malignant } \\
\text { lentigo }\end{array}$ & 1 & - & - & - & - & - & 1 & - & - & - & - \\
\hline \multirow[t]{2}{*}{ Total / \% } & 65 & 20 & 14 & 10 & 5 & 2 & 1 & 1 & 1 & 1 & 10 \\
\hline & & 30.7 & 21.5 & 15.3 & 7.6 & 3 & 1.5 & 1.5 & 1.5 & 1.5 & 15.3 \\
\hline
\end{tabular}

Source: HUCFF - UFRJ (1993-2003).

Key:

SSM: superficial spreading melanoma

UNM: ulcerated nodular melanoma

MLM: malignant lentigo melanoma
NM: nodular melanoma

ALM: acral lentiginous melanoma

MN: melanocytic nevus neoplastic cells; enlarged margins. Two-year follow-up.

Case 60: woman, 60 years old, white, nodular melanoma in abdomen, resection was performed with $1 \mathrm{~cm}$ margin, Breslow $2.3 \mathrm{~mm}$, impalpable axillary and inguinal lymph nodes. Axillary sentinel lymph nodes negative (one on the right and two on the left). Enlarged margins. Currently being seen on an outpatient basis.

The ambulatory routine avoids unnecessary exams and takes into account hospital costs; it is recommended (AJCC, 2002) that two dosages of lactic dehydrogenase (LDH) are done in 24-hour intervals.

The profile of the studied sample - prevalence in the age group from 40 to 69 years, white color - is in agreement with the respective Brazilian literature (Table 1). On the contrary, however, in the authors' cases, the distribution between sexes was homogeneous, predominant location in trunk (Tables 2, 3 and 4). The finding of a higher frequency of acral lentiginous type located in the foot among non whites has been established (Tables 1, 3 and 4).

In the Brazilian cases, the histological types described as predominant are nodular (Table 1) and superficial spreading (Table 1). It is also underscored that the classification of the tumor, several times, was only possible by also evaluating the clinical characteristics ${ }^{7}$ greater frequency of the superficial spreading type in private clinics and predominance of nodular type in patients seen at public services are referred by the same authors. ${ }^{7}$ In the present study, the predominant clinicalhistological type was SSM (Tables 2, 3 and 4).

In eight cases there were reports of melanocyt- ic nevus in childhood preceding the malignant lesion. It was not possible to evaluate if these were congenital or acquired. The histological types were defined as nodular $(\mathrm{n}=2)$, superficial spreading $(\mathrm{n}=3)$, desmoplastic $(\mathrm{n}=1)$, remains of melanocytic nevus $(n=1)$ and not classified $(n=1)$. The literature refers to a percentile of transformation that varied from 1 to $20 \% .^{27}$

Case 52 was classified histopathologically as desmoplastic, or that is, composed of groups of anaplastic and elongated cells, surrounded by abundant collagen with a hyaline aspect and that frequently presents bizarre nuclei and multinucleation, without pigment and without expression of antigen HMB45. The desmoplastic melanoma is described as an aggressive form, exclusive to the elderly, in exposed areas and in association with malignant lentigo; rare in blacks, high rate of local recurrence, significant risk of metastasis and elevated mortality. ${ }^{11}$ The male, white, 36-year-old patient referred to prior nevus lesion.

In 10 cases $(15.3 \%)$ of this series, the histological diagnosis was indefinite. In other published series, $4.4 \%,{ }^{28} 5 \%^{29}$ and $10 \%{ }^{30}$ of the cases were not classified. The overlap of characteristics between the various subtypes hinders their classification.

The final version of AJCC $2002^{21}$ only includes the ulcerated histological type in the staging of cutaneous melanoma. The presence or absence of ulceration is the only independent prognostic factor of primary melanoma in stages I, II and III (Chart 1). The term ulceration is descriptive for a biological event that exhibits an absence of epidermis over the tumor. 
TABLE 6: Distribution of the cases according to stage, AJCC 2002

\begin{tabular}{|c|c|c|c|c|c|c|c|c|c|c|c|c|}
\hline \multicolumn{13}{|c|}{ Follow-up } \\
\hline & \multicolumn{3}{|c|}{$6 \mathrm{~m}-1 \mathrm{yr}$} & \multicolumn{3}{|c|}{$>1 \mathrm{a}-<5 \mathrm{yr}$} & \multicolumn{3}{|c|}{$5 a-10 y r$} & \multirow{4}{*}{$\begin{array}{l}\text { Hospital } \\
\text { discharge }\end{array}$} & \multirow{3}{*}{\multicolumn{2}{|c|}{ Total / \% }} \\
\hline \multirow[t]{3}{*}{ Stage } & \multirow{2}{*}{\multicolumn{3}{|c|}{$\begin{array}{l}\mathrm{n}^{\mathrm{o}} \text { de of cases } \\
\text { Disease }\end{array}$}} & \multirow{2}{*}{\multicolumn{3}{|c|}{$\begin{array}{c}\mathrm{n}^{\mathrm{o}} \text { of cases } \\
\text { Disease }\end{array}$}} & \multirow{2}{*}{\multicolumn{3}{|c|}{$\begin{array}{c}\mathrm{n}^{\mathrm{o}} \text { of cases } \\
\text { Disease }\end{array}$}} & & & \\
\hline & & & & & & & & & & & & \\
\hline & Present & Absent & Deaths & Present & Absent & Deaths & Present & Absent & Deaths & & & \\
\hline $\mathrm{Tx}$ & - & - & - & - & 1 & - & - & - & - & - & 1 & 1.5 \\
\hline in situ & - & - & - & - & - & - & - & - & - & 14 & 14 & 21.5 \\
\hline IA & - & 3 & - & - & 7 & - & - & 12 & - & - & 22 & 33.8 \\
\hline IB & - & 2 & - & - & 4 & - & - & 2 & - & - & 8 & 12.3 \\
\hline IIA & - & 1 & - & - & 1 & - & - & 2 & - & - & 4 & 6.1 \\
\hline IIB & - & 3 & - & - & 1 & - & 1 & - & - & - & 5 & 7.6 \\
\hline IIC & - & - & - & - & - & - & - & - & - & - & - & - \\
\hline IIIA & 1 & 1 & - & - & - & - & - & 2 & - & - & 4 & 6.1 \\
\hline IIIB & 1 & - & - & 1 & - & - & - & - & - & - & 2 & 3 \\
\hline IIIC & 1 & - & - & - & - & - & - & - & - & - & 1 & 1.5 \\
\hline IV & 2 & - & 1 & - & - & 1 & - & - & - & - & 4 & 6.1 \\
\hline \multirow[t]{2}{*}{ Total / \% } & 5 & 10 & 1 & 1 & 14 & 1 & 1 & 18 & - & 14 & 65 & 100 \\
\hline & 7.6 & 15.3 & 1.5 & 1.5 & 21.5 & 1.5 & 1.5 & 27.6 & & 21.5 & & \\
\hline
\end{tabular}

Source: HUCFF - UFRJ (1993-2003).

Key:

yr: year $\quad m$ : month

$>$ : greater than $\quad<$ : less than

- : no case

Such a situation can be distinguished from artifact and traumatic events that lead to a partial absence of epidermis. In this case series, five ulcerated tumors (7.6\%) were found (Table 5).

In certain circumstances, the evaluation of Breslow's thickness partially hindered or becomes less necessary: accentuated inflammatory infiltrate, central ulceration on the thickest area, tumor on probable area of melanocytic nevus with difficult distinction between the benign and malignant cells. As it was seen in case 37 - female, white, 75 years old, nodular type in the back, three-year follow-up without disease. AJCC 2002 does not define the management of melanomas classified as Tx (indeterminate). It was opted for ambulatory attendance every two months (skin and lymph nodes) and chest $\mathrm{x}$-ray/tests of hepatic function every six months (Chart 1$)$.

More than half of the cases (36/55.3\%) were staged in the initial phases (in situ, IA), pointing to an earlier diagnosis (Chart 1 and Table 6). The overall five-year survival rate at the time of data analysis was $29.1 \%$ (19 cases) (Table 6).

Local recurrence defined as recurrence of the tumor in the radius (three to $5 \mathrm{~cm}$ ) starting from the primary closure or graft is considered rare (3.2\%). Ulceration and thickness of the primary tumor, and location in the head and neck are considered predis- posing factors. In case 8 , three years after resection of the primary tumor located in the scalp, a new lesion with $0.22 \mathrm{~mm}$ thickness and no histopathologic ulceration was observed. Exeresis of the new lesion gave a histopathologic diagnosis of melanoma in situ.

\section{CONCLUSIONS}

In the sample of 65 cases of cutaneous melanoma the following observations were made: prevalence in the age group from 40 to 69 years; homogeneous distribution between the sexes; prevalence of whites; superficial spreading melanoma as the predominant clinical-histological type; more frequent location in the trunk; and statistically significant relationship between acral lentiginous type located in the foot of non-whites. Over half of the cases presented initial stages of the disease (in situ and IA).

\section{ACKNOWLEDGEMENTS}

The authors thank: professors Cleide Eiko Ishida and Monica Manela-Azulay, and Dra. Luciana Souto (Dermatological Surgery); professor Irocy G. Knackfuss (Orthopedics) and Rosângela A. M. Noe (Commission for Scientific Investigation, HUCFF - UFRJ). 


\section{REFERENCES}

1. Friedman RJ, Heilman ER, Gottlieb GJ, Waldo ED, Rigel DS. Malignant melanoma: clinico pathologic correlations. In: Friedman RJ, Rigel DS, Kopf AW, Harris MN, Backer D, editors. Cancer of the skin. Philadelphia: WB Saunders; 1991. p.125-41.

2. Almeida FA, Almeida GOO, Michalany NS. Melanoma cutâneo. Aspectos clínicos. In: Neves RG, Lupi O, Talhari S, editores. Câncer de pele. Rio de Janeiro: Medsi; 2001. p.226-32.

3. Fernandes NC, Cardoso ICL, Maceira J, Perez M. Melanoma: estudo retrospectivo de 47 casos. An Bras Dermatol. 1996; 71:381-5.

4. Levit EK, Kagen MH, Scher R, Grossman M, Altman E. The $A B C$ rule for clinical detection of subungual melanoma. J Am Acad Dermatol. 2000; 42:269-74.

5. Harris MN, Roses DF. Malignant melanoma: treatment. In: Friedman RJ, Rigel DS, Kopf AW, Harris MN, Baker D, editors. Cancer of the skin. Philadelphia: WB Sawnders; 1991. p.177-197.

6. Pinheiro AMC, Cabral ALSV, Friedman H, Rodrigues HA. Melanoma cutâneo: características clínicas, epidemiológicas e histopatológicas no Hospital Universitário de Brasília entre janeiro de 1994 e abril de 1999. An Bras Dermatol. 2003; 78:179-86.

7. Maia M, Russo C, Ferrari N, Ribeiro MCS de A, Santos ABOS. Reflexões em relação à epidemiologia do melanoma cutâneo no Brasil. An Bras Dermatol. 2002; 77:163-70

8. Lapa MS, Guedes KF, Schalch FO, Landman G. Melanomas malignos cutâneos tratados no Hospital do Câncer de São Paulo. Estudo retrospectivo para avaliação de distribuição, fatores prognósticos e sobrevida. An Bras Dermatol. 2002; 77:313-20.

9. Bakos L, Wagner M, Bakos RM, Leite CS, Sperhacke CL, Dzekaniak KS, et al. Sunburn, sunscreens and pheno types: some risk factors for cutaneous melanoma in southern Brazil. Int J Dermatol. 2002; 41:557-62.

10. Gon AS, Minelli L, Guembarovski. Melanoma cutâneo primário em Londrina. An Bras Dermatol. 2001;76:413-26.

11. Criado PR, Vasconcellos C, Sittart JAS, Valente NYS, Moura BPS, Barbosa GL. Melanoma maligno cutâneo primário: estudo retrospectivo de 1963 a 1997 no Hospital do Servidor Público Estadual de São Paulo. Rev Assoc Med Bras. 1999; 45:157-62.

12. Ponzio HA. Freqüência de melanoma maligno no Serviço de Dermatologia da I SCMPA/UFRGS. An Bras Dermatol. 1998; 73(Supl 1):6-11.

13. Donato CA, Yokomizo V, Peres Rosa I. Melanoma maligno: avaliação de 58 casos em um período de 11 anos (jan/85 - dez/95). Med Cut Iber Lat Am. 1997; 25:265-9.

14. Castro LGM, Toyama CL, Gomes AP, Freire MA, Britto TF. Câncer de pele em clínica particular em São PauloSP. An Bras Dermatol. 1996; 76:471-6.

15. Bakos L. Melanomas malignos e etnia. An Bras Dermatol. 1991; 66:299-302.

16. Dick OW, Santos MLR, Santos FAR, Frischenbruder JA, Costa PG, Rocha VHB. Melanoma maligno: idade X estadiamento clínico: estudo retrospectivo de 161 casos. An Bras Dermatol. 1989; 64:151-3.

17. Minelli L, Pereira VL. Melanoma - estudo casuístico do Instituto de Câncer de Londrina. An Bras Dermatol. 1983; 58:81-4.

18. da Silva CSC, Fernandes NC. Tumores cutâneos. In Franco T, editor. Princípios de cirurgia plástica. São Paulo: Atheneu; 2002. p.185-96.

19. Rezende JFN, Fiod NJ. Tratamento cirúrgico das lesões de grande porte. In: Neves RG, Lupi O, Talhari S, editores. Câncer de pele. Rio de Janeiro: Medsi; 2001. p.556-72.

20. Fernandes NC. Rotinas da enfermaria de dermatologia. São Paulo: Atheneu; 2001. p.33-6.

21. Fernandes NC, Lemme RC, Maceira JP. Protocolo do melanoma cutâneo. In: Neves RG, Lupi O, Talhari S, edi tores. Câncer de pele. Rio de Janeiro: Medsi; 2001. p.268-71.

22. Lotze MT, Dallal RM, Kirkwood JM, Flickinger JC. Cutaneous melanoma. In: De Vita Jr VT, Hellman S, Rosenberg AS, editors. Cancer: principles and practice of oncology. Philadelphia: Lippincot Williams \& Wilkins; 2001. p.2012-69.

23. Balch CM, Buzaid AC, Svong SJ, Atkins MB, Coit DG, Fleming ID. Final version of the American Joint Committee on Cancer Staging System for Cutaneous Melanoma. J Clin Oncol. 2001; 19:3635-48.

24. Clark WH, From L, Bernardino EA, Mihm MC. The histogenesis and biologic behavior of primary human malignant melanomas of the skin. Cancer Res. 1969; 29:705-26.

25. Tovo LFR, Cerri GG. Diagnóstico por imagem em oncologia cutânea. In: Neves RG, Lupi O, Talhari S, editores. Câncer de pele. Rio de Janeiro: Medsi; 2001. p.466-74.

26. Neves RJ, Belfort FA, Brandão M, da Silva DCP, Jorge D, Parro F. Relatório final do Consenso Nacional sobre Linfonodo Sentinela (LNS) do Grupo Brasileiro de Melanoma. Acta Oncol Bras. 2003; 23:499-503.

27. Managment of congenital melanocytic nevi: a decade later. Pediatr Dermatol 1996; 13:312-40.

28. Richard MA, Grob JJ, Avril MF, Delaunay M, Thirion X, Wolkenstein P. Melanoma and tumor thickness. Challenges of early diagnosis. Arch Dermatol. 1999; 135:269-74.

29. Piñeiro-Maceira J. Diagnóstico histopatológico e indicadores prognósticos do melanoma. In: Neves RG, Lupi O, Talhari S, editores. Câncer de pele. Rio de Janeiro: Medsi; 2001. p.260-7.

30. Sanderson KV, Mackie R. Tumours of the skin. In: Rook A, Wilkinson DS, Ebling FJG, editors. Textbook of dermatology. London: Blackwell; 1982. p.2129-31.

\author{
MAILING ADDRESS: \\ Nurimar C. Fernandes \\ Rua Alexandre de Gusmão, 28 / 201 \\ 20520-120 Rio de Janeiro RJ \\ Tel/Fax: (21) 2568-4158*51 \\ E-mail: nurimarfernandes@aol.com
}

